\title{
Blast-off approaches for eagle-eyed orbiter
}

\section{Sally Goodman, Paris}

Preparations for the launch on 1 March of Envisat, the Earth-observation satellite developed by the European Space Agency (ESA) at a cost of 2.3 billion euros (US $\$ 2.0$ billion), are reaching their final stages in Kourou, French Guiana.

Envisat weighs $8,300 \mathrm{~kg}$ and carries 10 different instruments - an usuallylarge number for an individual satellite. Data from the satellite will find a wide range of uses, from the development of climate models to the calibration of greenhouse-gas emission targets.

The launch was put back from last October after problems with the upper stages of the Ariane 5 launch rocket led to another ESA satellite, Artemis, being placed in the wrong orbit (see Nature 412, 368; 2001). The rocket's developers - Arianespace, based in Evry, south of Paris - say they have now corrected the problem, which was caused by frozen water blocking the fuel-injection system.

Sensors on board Envisat will measure parameters such as sea level and temperature, and the spectrum of the solar radiation reflected by the Earth. Existing satellites capture some similar data, but Envisat will allow them to be studied simultaneously. It will also provide new data, such as measurements of trace atmospheric gases. "Combined measurements are the key to understanding phenomena like El Niño," says José Achache, head of ESA's Earth-observation programme.

Envisat also carries a sensor for measuring ocean chlorophyll and terrestrial biomass, which will improve measurements of plant productivity. Such data will help to determine greenhouse-gas emission targets

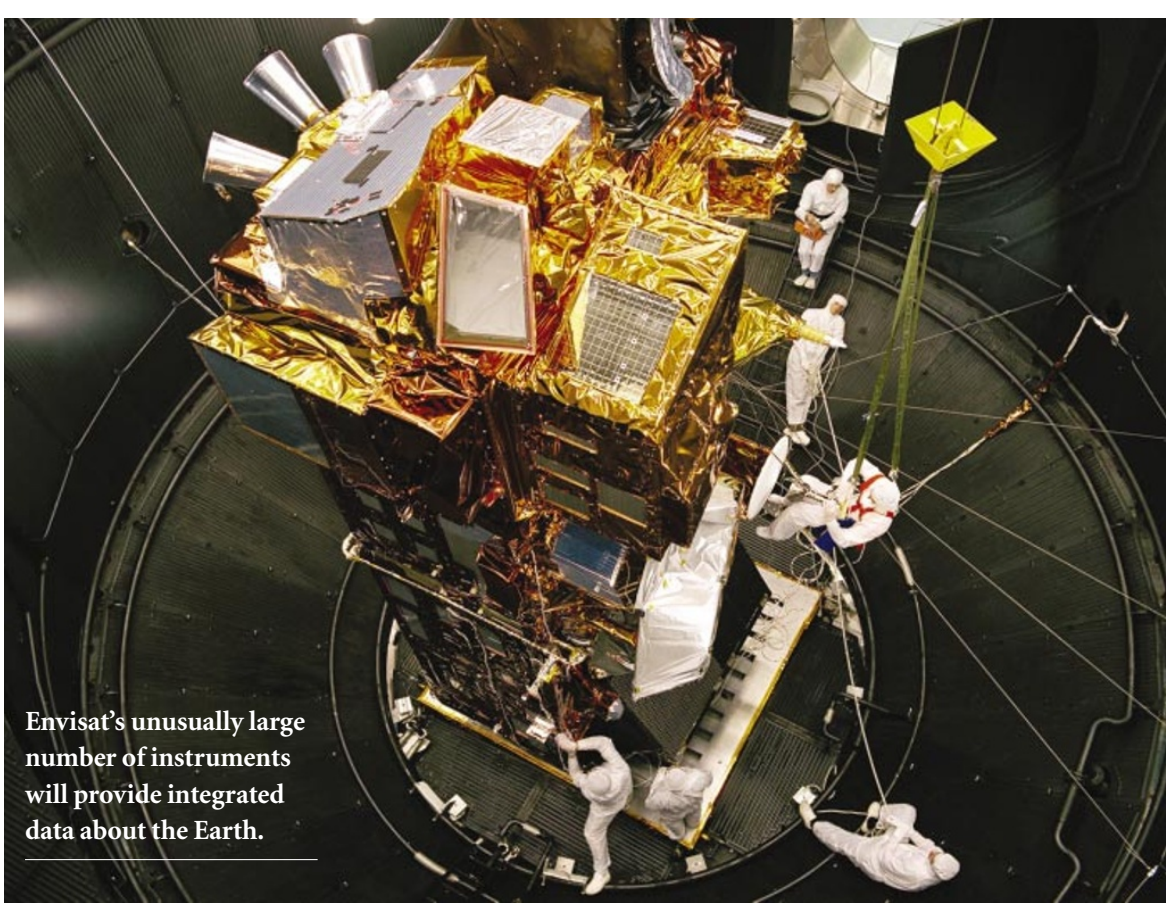

by providing accurate measurements of the amount of carbon absorbed by oceans and by large areas of vegetation, such as the boreal forests of Europe and Asia.

Over 700 groups of scientists, including 150 from the United States, have already been given clearance by ESA to work with the data, much of which will be made available over the Internet. But some at the agency say that in the future there may not be enough trained researchers and resources to make the most of the huge amount of data Envisat will provide. "Now Envisat is here, the biggest challenge for Europe's funding agencies is to make sure it can be properly exploited," says David Southwood, director of science at ESA.

Despite Envisat's wide range of applications, ESA is unlikely to launch another satellite of its size. Future European Earthobservation missions will use smaller satellites, tailored in part to meet the needs of a new plan by ESA and the European Commission to create a global network of satellites to provide data on security issues and the environment (see Nature 414, 140; 2001).

http://envisat.esa.int

\section{Reduced funding feeds Danish scientists' resentment}

\section{David Adam, London}

Something is rotten in the state of Denmark, say researchers there who are facing funding cuts. In a bid to improve the country's social welfare system, the new Liberal-Conservative coalition government says it must drain money from universities, research councils and its own independent labs.

Denmark spends about DKr12 billion (US\$1.4 billion) of public money on research each year, and some DKr10 billion on the country's higher education system. The new government, elected on 20 November last year, wanted to cut university funding by $6 \%$, but was forced on 4 February to reduce this to 2\% — about DKr200 million — after industry and other political parties protested.

"DKr200 million may sound very little, but Denmark is a small country," says Jens Rehfeld, a protein chemist at the University of Copenhagen's hospital. He says that the new administration has already "sent out a very bad signal to science".

Funding for the country's research councils is also set to fall. Currently standing at DKr1 billion annually, it will drop to about DKr650 million by the end of 2004, as several programmes that began in the mid-1990s finish and are not replaced. Jens Christian Djurhuus, chairman of the Danish Medical Research Council, says this will reduce the number of $\mathrm{PhD}$ students by about $20 \%$, just as the biotechnology industry is calling for their numbers to be doubled. "Our position in the international community will be severely weakened," he says.

Dan Jensen, head of research at the newly formed Ministry of Science, Technology and Innovation, admits that the fears are justified. "There is truth behind these complaints," he says. "Everybody has to pay for social welfare." However, he says that the government intends to channel DKr400 million from the sale of mobile-phone licences into research.

One early casualty of cutbacks is the small-satellite programme at the Danish Space Research Institute in Copenhagen. The programme's funding has been withdrawn by the government, raising doubts over the institute's Rømer satellite, which was intended to analyse light from nearby stars.

Danish participation in CERN, the European particle-physics laboratory near Geneva, to which the country currently contributes DKr100 million a year, could also be affected. "We're approaching a bare-bones situation now," says Ole Hansen, a physicist at the Niels Bohr Institute in Copenhagen. "It's difficult to see how we can continue our involvement on a decent level." 